\title{
PENERAPAN METODE PEMBELAJARAN TEAM GAMES TOURNAMENT (TGT) DALAM MENINGKATKAN KETERAMPILAN PERMAINAN BOLA KASTI MATA PELAJARAN PENJASKES PADA SISWA KELAS V SD NEGERI 163099 TEBING TINGGI
}

\author{
Sabarina Br. Barus \\ Surel : sabarinabarus03@gmail.com
}

\begin{abstract}
This purposes of this research is to improve learning result on physical education subject through team games tournament (TGT) method. This classroom action research conducted by 2 cycles of the four phases: planning, implementation, observation, reflection. The subjects were students from grade V SD Negeri 163099 Tebing Tinggi which amounted to 32 students. The source of the data from observer, students and teacher. Data collection are by test and observation. This research used a qualitative descriptive analysis technique with percentage. The results showed that the use of TGT method at physical education can improve the ability of hitting and throwing in baseball which is characterized by increased mastery learning students, namely pre-cycle (59,37\%), cycle I (81,25\%), Cycle II $(93,75 \%)$ and complete learn the clasical equal to 93,75\% in cycle II.
\end{abstract}

Keywords: Hitting, Throwing, Baseball

\begin{abstract}
ABSTRAK
Penelitian ini bertujuan untuk meningkatkan hasil belajar siswa mata pelajaran Penjaskes melaui metode pembelajaran latihan metode Team Games Tournament (TGT) Penelitian tindakan kelas ini dilaksanakan sebanyak 2 siklus dengan empat tahapan yaitu : perencanaan, pelaksanaan, observasi, refleksi. Subjek penelitian ini adalah siswa kelas V SD Negeri 163099 Tebing Tinggi sebanyak 32 siswa. Sumber data berasal dari guru, peserta didik dan peneliti. Teknik pengumpulan data adalah dengan tes dan observasi. Penelitian ini menggunakan teknik analisis deskriptif kualitatif yang dengan presentase. Hasil penelitian menunjukkan bahwa penggunaan metode TGT mata pelajaran Penjaskes dapat meningkatkan kemampuan memukul dan melempar bola kasti yang ditandai dengan peningkatan ketuntasan belajar siswa, yaitu pra siklus $(59,37 \%)$, siklus I $(81,25 \%)$, siklus II $(93,75 \%)$ dan dinyatakan berhasil ssecara klasikal 93,75\% pada siklus II.
\end{abstract}

Kata Kunci: Memukul, Melempar, Kasti

\section{PENDAHULUAN}

Pendidikan

merupakan bagian integral dari

pendidikan secara keseluruhan, bertujuan untuk mengembangkan aspek kebugaran jasmani, keterampilan gerak, keterampilan berfikir kritis, keterampilan sosial, penalaran, stabilitas emosional, tindakan moral, aspek pola hidup sehat, dan pengenalan lingkungan hidup bersih melalui aktivitas jasmani, olahraga, dan kesehatan terpilih yang direncanakan secara 
sistematis dalam rangka mencapai tujuan pendidikan nasional (BSNP, 2006 : 248).

Pembelajaran pendidikan jasmani di sekolah dasar adalah untuk meningkatkan kebugaran jasmani, mengembangkan keterampilan motorik, pengetahuan dan perilaku hidup sehat, sikap sportif, dan kecerdasan emosi. Menurut Ridwan dan Ikman Sulaeman (2008: 12) Kasti merupakan salah satu jenis permainan bola kecil. Permainan kasti termasuk permainan beregu. Permainan ini mengutamakan kegembiraan dan ketangkasan para pemainnya. Untuk dapat memenangkan permainan, satu regu dituntut untuk bekerja sama dengan baik.

Dalam kehidupan sehari-hari kemampuan gerak sangat dibutuhkan baik untuk menyelesaikan pekerjaan sehari-hari secara individu maupun secara kelompok. Menurut Munandar (2002: 17) kemampuan adalah daya untuk melakukan suatu tindakan sebagai hasil dari pembawaan dan latihan. Menurut Uno (2011 : 8) Dalam praktek pengajaran, penggunaan suatu teori dasar untuk segala situasi merupakan suatu tindakan kurang bijaksana, tidak ada suatu teori yang cocok untuk segala situasi karena masing-masing mempunyai landasan yang berbeda dan cocok untuk situasi tertentu

Pembelajaran yang terjadi selama ini, khususnya dalam pembelajaran bola kasti adalah pembelajaran yang hanya memfokuskan pada gerak dasar dan tidak memperhatikan permainan apa yang dapat diterapkan. Oleh karena itu siswa akan cepat bosan dalam menerima pembelajaran. Hasil tes praktek awal pada siswa kelas V SD Negeri 163099 Tebing Tinggi dalam permainan bola kasti, hanya 19 siswa $(59,37 \%)$ yang mampu melakukan teknik lempar dan tangkap permainan bola kasti. Sedangkan 13 siswa (40,63 $\%)$ belum mampu melakukan teknik melempar dan menangkap bola dengan benar. Hal ini menyebabkan hasil pembelajaran masih jauh dari yang diharapkan.

Dalam hal itu dikarenakan guru pendidikan jasmani memiliki kecenderungan menggunakan cara yang sama untuk mengajar pendidikan jasmani, jadi guru tidak memiliki inisiatif maupun tindakan terhadap siswa yang kurang memperhatikan apa yang sedang diajarkan saat pembelajaran berlangsung. Oleh karena itu diperlukan suatu tindakan yang mampu melibatkan partisipasi siswa dan sekaligus dapat digunakan untuk mempermudah siswa dalam mengikuti proses pembelajaran demi tercapainya tujuan pembelajaran yang direncanakan.

TGT merupakan prosedur pembelajaran yang memberikan kesempatan kepada kelompok untuk berkompetisi dengan kelompok lain sehingga siswa bergairah belajar (Slavin dalam Abidin, 2014: 254). Team Games Tournament melibatkan aktivitas seluruh siswa tanpa harus ada perbedaan status, melibatkan peran siswa sebagai tutor teman sebaya dan mengandung 
Sabarina Br. Barus : Penerapan Metode Pembelajaran ...

aturan game tournament dalam pembelajaran (3) Guru memulai Team Games Tournament dengan materi yang sudah dipelajari dan memberikan teknik penilaian dalam memukul bola kasti yang telah disediakan dalam beberapa babak dalam permainan. (4). Setiap kelompok berusaha mendapatkan nilai tertinggi dengan strategi yang telah mereka susun dalam kompetisi permainan dengan menjawab soal yang telqah diberikan.

Dalam setiap tahap pembelajaran yang diterapkan, masing-masing berisi langkahlangkah pembelajaran yang terdiri atas team, game dan tournament. Pada saat kegiatan pembelajaran berlangsung guru sebagai peneliti dibantu oleh para observer lainnya untuk melakukan pengamatan, pendokumentasian. Pelaksanaan penelitian ini mengikuti tahap-tahap penelitian tindakan kelas yang terdiri atas pengamatan, pendahuluan/ perencanaan, dan pelaksanaan tindakan. Pelaksanaan tindakan terdiri atas beberapa siklus, setiap siklus terdiri atas tahap perencanaan tindakan, pemberian tindakan, observasi, dan refleksi.

\section{Siklus II}

Penerapan metode TGT dilakukan dengan menugaskan kepada masing-masing siswa untuk latihan melempar bola kasti dengan teknik-teknik yang telah diajarkan oleh guru. Kegiatan pada siklus kedua ini juga hampir sama dengan siklus I namun materi yang diberikan berbeda yaitu teknik memukul bola. Hal-hal yang dianggap kurang pada siklus I diperbaiki dalam siklus II.

\section{Observasi/Pengamatan}

Pengamatan dilakukan peneliti sendiri dan dibantu oleh pengamat dan mencatat proses penerapan teknik pengajaran kolaborasi. Hasil observasi yang telah dicatat kemudian didiskusikan bersama untuk menentukan rencana tindakan yang akan dilaksanakan pada proses pembelajaran.

\section{Refleksi}

Peneliti mengkaji, melihat dan mempertimbangkan hasil atau dampak dari tindakan yang dilakukan berdasarkan lembar pengamatan yang diisi oleh pengamat. Tahapan ini dilakukan secara berkesimbungan sehingga ditemukan hasil yang optimal Kegiatan pada tahap refleksi meliputi kegiatan menganalisis, memahami dan membuat kesimpulan berdasarkan hasil observasi setiap siklus. Menemukan kelebihan dan kelemahan tindakan perbaikan pembelajaran.

Metode pengumpulan data penelitian ini adalah praktik dan observasi. Penelitian ini dikatakan berhasil apabila siswa telah memperoleh nilai ketuntasan secara klasikal minimal $85 \%$ dari jumlah siswa dengan rumus sebagai berikut :

Persentase Ketuntasan klasikal $=$

Jumlah siswa yang tuntas $\quad$ x $100 \%$ Jumlah siswa yang mengikuti tes 


\section{HASIL PENELITIAN DAN PEMBAHASAN}

Data yang diperoleh melalui hasil observasi pada pra siklus terlihat bahwa persentase aktivitas siswa yang diamati termasuk dalam kategori belum tuntas. Hal ini dapat dilihat dari pemahaman atau penguasaan teknik memukul dan melempar masih rendah yaitu hanya sebesar 59,37\% atau dapat dikatakan hanya 21 siswa yang tuntas belajar dalam melakukan teknik memukul dan melempar dengan baik. Selain itu sumber belajar yang dimiliki peserta didik sangat terbatas jika mengandalkan guru, sehingga kemampuan peserta didik tidak berkembang dengan aktif. Aktivitas peserta didik yang pasif dalam proses pembelajaran disebabkan oleh peran guru yang kurang dalam membimbing dan mengarahkan peserta didik. Masalah tersebut dapat membuktikan alasan kenapa nilai peserta didik pada kegiatan pre-test masih banyak dibawah KKM. Selanjutnya peneliti melakukan refleksi terhadap hasil yang diperoleh ini dengan melakukan tindakan siklus I untuk mengetahui dan meningkatkan kemampuan memukul dan melempar dengan metode TGT.

Hasil penelitian tindakan kelas menunjukkan bahwa pengamatan yang dilakukan oleh mitra kolaborasi dan peneliti pada aktivitas guru dan siswa melalui penerapan latihan metode $T G T$ pada mata pelajaran penjaskes materi teknik memukul dan melempar permainan bola kasti pada siswa kelas
V SD Negeri 163099 Tebing Tinggi dapat dilihat pada Tabel 1 yaitu sebagai berikut :

Tabel 1. Peningkatan Hasil Belajar Siswa Siklus I dan II

\begin{tabular}{c|c|c|c}
\hline \multirow{2}{*}{ Keterangan } & \multicolumn{3}{|c}{$\begin{array}{c}\text { Peningkatan Hasil } \\
\text { Belajar }\end{array}$} \\
\cline { 2 - 4 } & $\begin{array}{c}\text { Pra } \\
\text { siklus }\end{array}$ & $\begin{array}{c}\text { Sikus } \\
\text { I }\end{array}$ & $\begin{array}{c}\text { Siklus } \\
\text { II }\end{array}$ \\
\hline Jumlah & 19 & 26 & 30 \\
\hline $\begin{array}{c}\text { Keaktifan Siswa } \\
(\%)\end{array}$ & 50,5 & 75 & 83,4 \\
\hline $\begin{array}{c}\text { Persen } \\
\text { Ketuntasan } \\
\text { Belajar (\%) }\end{array}$ & 59,37 & 81,25 & 93,75 \\
\hline \multicolumn{2}{c}{}
\end{tabular}

Berdasarkan Tabel 1 menunjukkan hasil belajar teknik memukul dan melempar bola kasti pada siswa Kelas V SD Negeri 163099 Tebing Tinggi tahun pelajaran 2018/2019 mengalami peningkatan. Jumlah siswa yang tuntas pada prasiklus sebanyak 19 siswa, kemudian diterapkan model pembelajaran kooperatif tipe team game tournament (TGT) ketuntasan hasil belajar menjadi 30 siswa, sehingga peningkatannya yaitu 10 . Siswa bisa dikatakan tuntas pada siklus II untuk hasil belajarnya karena mencapai persentase ketuntasan yang diharapkan yaitu $\geq 85 \%$.

Kemampuan bermain bola kasti terdiri dari berbagai unsur yaitu keterampilan memukul, melempar dan menangkap. Bagaimana dalam bentuk memukul dan melempar bola Semata-mata tetapi harus dilakukan secara permainan yang menarik sehingga tidak membosankan anak. 
Sabarina Br. Barus : Penerapan Metode Pembelajaran ...

Siswa yang mempunyai kemampun bermain bagus gerak dasarnya tentu bagus, unsur memukul, melempar dan menangkap akan memberikan kategori tersendiri untuk kemampuan bermain. Siswa memiliki keterampilan melempar, memukul dan menangkap, hanya saja belum bisa maksimal dalam pencapaiannya. Siswa harus melakukan latihan gerak dasar secara rutin supaya kemampuan dalam bermain bola kasti menjadi baik.

Terlihat bahwa siklus pertama aktivitas siswa mencapai $75 \%$ kemudian pada siklus kedua mencapai $83,4 \%$. Hal ini berarti ada peningkatan $8,4 \%$ setelah ada perbaikan pada siklus kedua. Pada siklus I materi yang diajarkan adalah teknik memukul bola. Memukul bola hendaknya yang rendah-rendah saja supaya lawan tak ada kesempatan untuk membuat bola tangkap. Apabila ditiang pertolongan banyak kawan. Untuk memberi kesempatan kepada kawan-kawan itu supaya dapat lari ketiang bebas, maka bola berganti-ganti dipukul kekiri dan kekanan. Apabila ditiang bebas banyak kawan yang akan masuk. Supaya kawan-kawan itu dapat. lari pulang kurang bebas maka bola harus dipukul tinggi sekali hingga jatuh jauh dibelakang. Pemukul yang pertama kesamping kiri atau ke kanan supaya teman-temannya dari pertolongan dapat lari ketiang bebas.

Pada siklus II pembelajaran teknik melempar bola diperoleh ketuntasan belajar 93,75 \%. Hasil tersebut menunjukkan bahwa pada kedua secara klasikal siswa sudah tuntas belajar, karena siswa yang memperoleh nilai $\geq 70$ sebesar $90 \%$ lebih besar dari persentase ketuntasan yang dikehendaki yaitu sebesar $80 \%$. Bola dilempar kepada kawan untuk ditangkap yang bertujuan untuk mematikan lawan. Lemparan yang dilakukan dari dekat sekali tidak mengenai sasarannya. Untuk dapat bermain kasti dengan baik, seorang pemain dituntut untuk dapat memegang bola dengan baik dan pandai melemparkan bola. Ada beberapa cara melempar bola kasti, antara lain lemparan melambung dan lemparan lurus atau datar.

\section{Pembahasan}

Hasil pengamatan peneliti di atas mengandung makna TGT menambah semangat dalam belajar karena secara tidak langsung peserta didik berusaha mendapatkan poin tertinggi, dalam proses pembelajaran berlangsung tak luput dari perselisihan kelompok, disinilah letak kooperatif juga berberan. Peserta didik belajar menghargai pendapat satu sama lain dan mempererat persahabatan diantara peserta didik. Sehingga dapat terbentuk karakter yang baik pada peserta didik. Hal tersebut diatas juga sesuai dengan pendapat Slavin dalam Abidin (2014: 254) bahwa TGT merupakan prosedur pembelajaran yang memberikan kesempatan kepada kelompok untuk berkompetisi dengan kelompok lain sehingga siswa bergairah belajar. 
Metode pembelajaran permainan kasti melalui team games tournament yang dapat meningkatkan aktifitas gerak siswa dan menjadikan siswa lebih aktif, karena dalam permainan ini dibutuhkan aktifitas gerak berlari, melempar dan melompat, serta koordinasi tubuh yang baik sehingga siswa dapat aspek ketangkasan dan kelincahan siswa dapat tercapai di dalam pembelajaran pendidikan jasmani. Siswa yang mempunyai kemampun bermain bagus gerak dasarnya tentu bagus, unsur memukul, melempar dan menangkap akan memberikan kategori tersendiri untuk kemampuan bermain.

Berdasarkan hasil yang didapat dari setiap siklus proses pembelajaran yang optimal, hal ini ditunjukkan dengan meningkatnya penguasaan materi dan hasil belajar siswa. Oleh karena itu dapat disimpulkan bahwa proses pembelajaran dengan penerapan metode Team Games Tournament sesuai dengan mata pelajaran penjaskes materi memukul dan melemar bola kasti. maka Penelitian Tindakan Kelas (PTK) ini bisa dikatakan berhasil karena hasil peningkatan proses pembelajarannya optimal.

\section{SIMPULAN}

Berdasarkan dari hasil temuan penelitian dan pembahasan tentang penerapan metode Team Games Tournament (TGT) di kelas V SD Negeri 163099 Tebing Tinggi tahun pelajaran 2018/2019 berdampak positif dalam meningkatkan kemampuan teknik memukul dan melempar bola kasti. Peningkatan kemampuan tersebut dapat dikatakan optimal dilihat berdasarkan dari hasil data observsai dan dokumentasi yang diperoleh pada setiap siklusnya. Hal tersebut dapat dilihat dari peningkatan persentase ketuntasan belajar siswa pada siklus I $(81,25 \%)$ dan siklus II $(93,75 \%)$ serta dinyatakan berhasil.

\section{DAFTAR RUJUKAN}

Abidin, Yunus. 2012. Desain Sistem Pembelajaran dalam Konteks Kurikulum 2013. Bandung: Refika Aditama.

BSNP. 2006. Standar Isi Sekolah Dasar/Madrasah Ibtidaiyah. Jakarta : Depdikbud.

Mulyatiningsih, Endang. 2014. Metode Penelitian Terapan Bidang Pendidikan. Yogyakarta: Alfabeta.

Munandar, Utami. 2002. Kreativitas dan Keterbakatan. Jakarta: Gramedia Pustaka Media.

Uno, Hamzah. 2011. Perencanaan Pembelajaran. Jakarta: Bumi Aksara.

Ridwan, I dan Ikman Sulaeman. 2008. Atletik. Solo: Widya Duta Grafika.

Slavin, Robert E.. 2010. Cooperative Learning Teori, Riset dan Praktik. Bandung: Nusa Media.

Taniredja, Tukiran. 2012. ModelModel Pembelajaran Inovatif. Bandung: Alfabeta. 